EXTENDED REPORT

\title{
Possible role of leptin in hypoandrogenicity in patients with systemic lupus erythematosus and rheumatoid arthritis
}

\author{
P Härle, G Pongratz, C Weidler, R Büttner, J Schölmerich, R H Straub
}

Ann Rheum Dis 2004;63:809-816. doi: 10.1136/ard.2003.011619

See end of article for authors' affiliations

Correspondence to: Professor R H Straub, Laboratory of Neuro/ endocrino/immunology, Department of Internal Medicine I, University Hospital Regensburg, D-93042 Regensburg, Germany; rainer.straub@ klinik.uni-regensburg.de

Accepted 26 July 2004

\begin{abstract}
Background: Hypoandrogenicity is common in obesity and in chronic inflammatory diseases such as systemic lupus erythematosus (SLE) and rheumatoid arthritis (RA). Adrenal androgens such as androstenedione (ASD) and dehydroepiandrosterone (DHEA) sulphate are low, which partly depends on the influence of TNF in chronic inflammatory diseases. Leptin is stimulated by TNF and is associated with hypoandrogenicity in non-inflammatory conditions.

Objective: To study the interrelation between serum levels of leptin and adrenal steroids in SLE and RA. Methods: In a retrospective study, serum levels of leptin, ASD, DHEA, and 17-hydroxyprogesterone (17OHP) were measured by ELISA, and serum levels of cortisol by radioimmunoassay in 30 patients with RA, 32 with SLE, and 54 healthy control subjects (HS).

Results: In SLE and RA but not HS, serum levels of ASD correlated negatively with serum levels of leptin $(p<0.01)$ independently of prior prednisolone treatment in patients with SLE $(p=0.013)$ and tended to be independent of prednisolone in patients with RA $(p=0.067)$. In a partial correlation analysis, this interrelation remained significant after controlling for daily prednisolone dose in both patient groups. In both patient groups, serum leptin levels correlated negatively with the molar ratio of serum ASD/serum cortisol and serum ASD/serum 17OHP, and positively with the molar ratio of serum DHEA/serum ASD. Conclusions: The negative correlation of serum leptin and ASD or, particularly, ASD/17OHP, together with its known anti-androgenic effects indicate that leptin is also involved in hypoandrogenicity in patients with SLE and RA. Leptin may be an important link between chronic inflammation and the hypoandrogenic state.
\end{abstract}

obese state, the fat tissue hormone leptin was found to have a dominant role for hypoandrogenicity because leptin inhibits gonadal androgen secretion..$^{29-31}$ Furthermore, a recent study in bovine adrenocortical cells demonstrated leptin induced inhibition of $17 \alpha$-hydroxylase P450 mRNA expression, ${ }^{32}$ which is the key enzyme for androgen production (fig 1). The same study demonstrated leptin induced inhibition of P450c21 and P450scc mRNA expression (fig 1). In addition, the same group showed that a similar inhibitory influence of leptin exists on human adrenocortical cells (reviewed by Glasow and Bornstein ${ }^{33}$ ) (fig 1). Thus, leptin may be an important factor for hypoandrogenicity in obese people and also in chronic inflammatory diseases.

This study aimed at investigating serum leptin levels in relation to serum concentration of adrenal androgens in patients with chronic inflammatory diseases. To estimate a possible influential role of leptin at the $\mathrm{P} 450 \mathrm{cl}$ (7) and $3 \beta$ hydroxysteroid dehydrogenase level, the interrelation of serum leptin and several molar steroid hormone ratios was investigated. We focused on patients with SLE and RA in order to demonstrate possible disease-unspecific changes.

\section{METHODS}

Healthy subjects and patients

We included 30 white patients with RA fulfilling the American College of Rheumatology criteria for diagnosis. ${ }^{34}$ Disease activity was assessed by the number of swollen and tender joints and erythrocyte sedimentation rate. Furthermore, we enrolled 32 white patients with SLE

Abbreviations: ASD, androstenedione; DHEA, dehydroepiandrosterone; ELISA, enzyme linked immunosorbent assay; HS, healthy subjects; 17OHP, 17-hydroxyprogesterone; RA, rheumatoid arthritis; SLE, systemic lupus erythematosus; TNF, tumour necrosis factor manifestations of the metabolic syndrome decreases the abdominal fat mass and reverses glucose intolerance. ${ }^{28}$ In the 


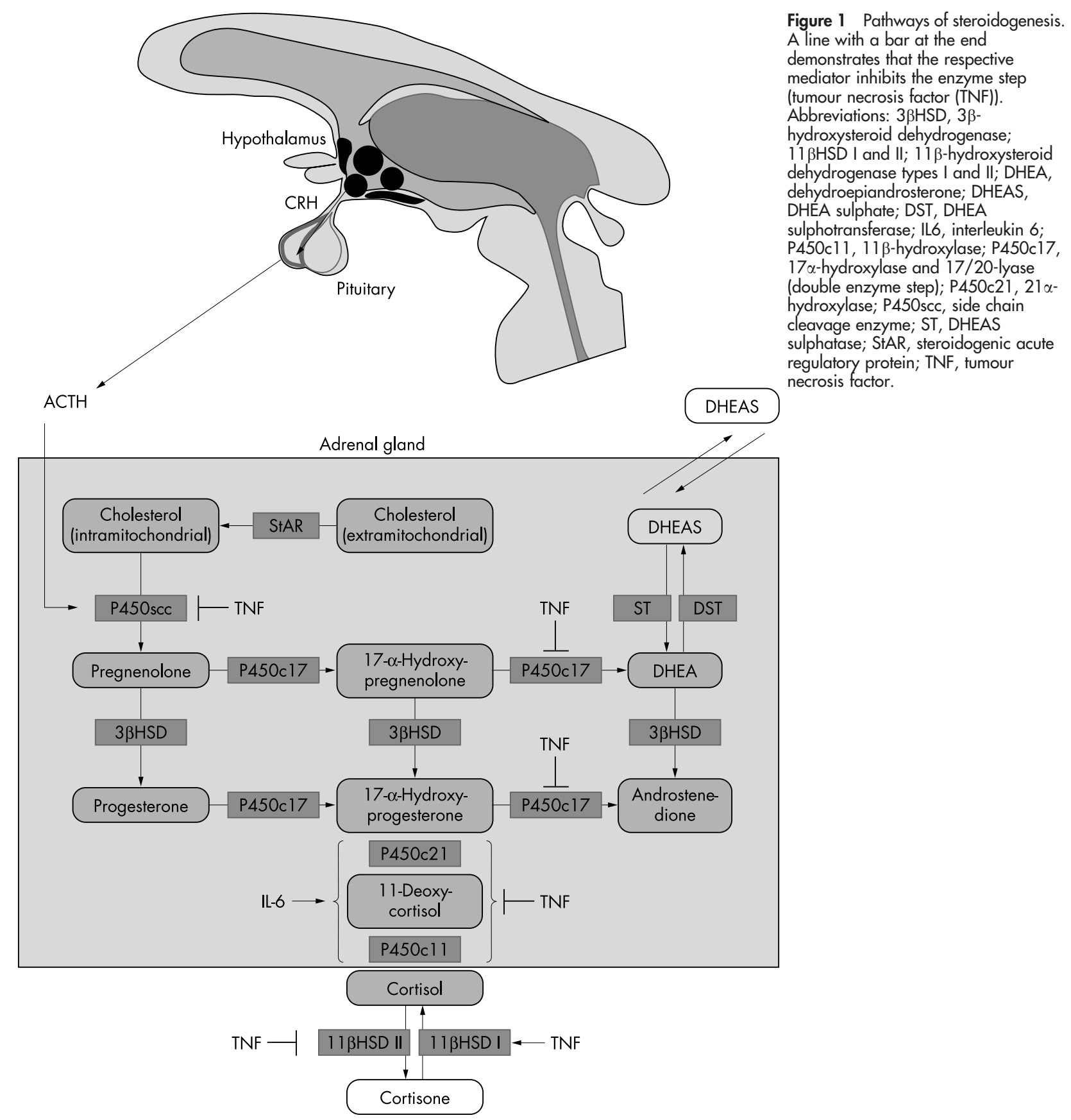

according to the criteria of the American College of Rheumatology. ${ }^{35}$ In the latter patients, clinical activity was assessed by the SLE Disease Activity Index (SLEDAI). Table 1 shows the basic characteristics of both disease groups and their treatment. Clearly, patients in both disease groups presented mild to moderate disease activity. Patients of both disease groups entered the study consecutively between 2000 and 2002. Some of the patients with RA and SLE were the subject of a recent study which dealt with other aspects of these diseases (manuscript submitted).

For comparison, 54 white healthy control subjects (HS) were included (mean (SEM) age 40.8 (1.5) years), and their health status was verified by a 33 item questionnaire, as previously described.$^{36}$ Fertile women (HS and patients) were not taking contraceptives and they were in the early to midfollicular phase of the menstrual cycle as estimated by serum progesterone levels (table 1). Information about the HS was collected between 2000 and 2002 as part of another investigation which dealt with different aspects (see above, manuscript submitted).

Because this was a retrospective study, we did not measure body mass and body height so that comparisons of serum leptin levels between groups were not made. Our intention was to focus only on relations between serum levels of leptin and adrenal steroids within the respective groups. Because we would expect raised leptin levels in subjects with increased body mass index, the mentioned significant correlations may be explained by the subjects' body mass index. We believe that the missing body mass index did not markedly influence our report.

On the day of the visit, between 800 and $1000 \mathrm{am}$, blood for further determination of leptin and steroid hormones was taken, and serum was stored at $-30^{\circ} \mathrm{C}$ in adequate aliquots. All patients and HS gave written consent for further 
Table 1 Basic characteristics of healthy subjects and patients with systemic lupus erythematosus (SLE) and rheumatoid arthritis (RA). The patients should not be compared owing to a different mean age of the groups.

\begin{tabular}{llll}
\hline & SLE & RA & Healthy subjects \\
\hline Number & 32 & 30 & 54 \\
Age (years) & $38.1(2.1)$ & $56.1(2.4)$ & $40.8(1.5)$ \\
Sex (F/M), No (\%) & $24 / 8(75 / 25)$ & $22 / 8(73 / 27)$ & $26 / 28(48 / 52)$ \\
Disease duration (years) & $8.0(1.5)$ & $10.8(1.9)$ & $\mathrm{NA}$ \\
SLEDAl (points) & $10.1(1.5)$ & $\mathrm{NA}$ & $\mathrm{NA}$ \\
Number of swollen joints & $\mathrm{NA}$ & $4.1(1.5)$ & $\mathrm{NA}$ \\
Number of painful joints & $\mathrm{NA}$ & $6.6(1.6)$ & $\mathrm{NA}$ \\
Serum progesterone (nmol/I)* & $2.6(0.4)[0.0-6.32]$ & $1.5(0.3)[0.1-5.0]$ & $3.0(0.4)[0.2-6.3]$ \\
ESR (mm/1st h) & $25.0(3.3)$ & $27.7(3.9)$ & $\mathrm{NM}$ \\
& & & \\
Drugs & $22(69)$ & $20(67)$ & $\mathrm{NA}$ \\
Prednisolone, No (\%) & $9.4(3.4)$ & $6.5(1.8)$ & $\mathrm{NA}$ \\
Prednisolone (mg/day) & $2(6)$ & $9(30)$ & $\mathrm{NA}$ \\
Methotrexate, No (\%) & $13(41)$ & $11(37)$ & $\mathrm{NA}$ \\
NSAIDs, No (\%) & $0(0)$ & $8(27)$ & $\mathrm{NA}$ \\
Leflunomide, No (\%) & $\mathrm{NA}$ & $\mathrm{NA}$ \\
Anti-TNF strategy, No (\%)† & $0(0)$ & $2(7)$ & $\mathrm{NA}$ \\
Sulfasalazine, No (\%) & $2(6)$ & $0(0)$ & $\mathrm{NA}$ \\
Cyclophosphamide, No (\%) & $12(38)$ & $0(0)$ & $\mathrm{NA}$ \\
Azathioprine, No (\%) & & & \\
\hline
\end{tabular}

Data are given as means (SEM), No (\%), and ranges in brackets.

${ }^{*}$ Mean serum level of progesterone in women (normal range in the follicular phase $<6.5 \mathrm{nmol} / \mathrm{l}$ ); †anti-TNF strategies were either infliximab or etanercept.

ESR, erythrocyte sedimentation rate; NA, not applicable; NM, not measured; NSAIDs, non-steroidal antiinflammatory drugs; SLE, systemic lupus erythematosus; SLEDAI, SLE Disease Activity Index.

investigation of their blood samples. Patients and HS lived in the catchment area of the University Hospital Regensburg, Bavaria.

\section{Laboratory parameters}

Radioimmunometric assay was used for the quantitative determination of serum levels of cortisol (Coulter Immunotech, Marseilles, France; detection limit $10 \mathrm{nmol} / \mathrm{l}$; cross reactivity with prednisolone $\leqslant 6 \%$ ). Serum levels of ASD (IBL, Hamburg, Germany; detection limit $0.15 \mathrm{nmol} / \mathrm{l}$ ), 17-hydroxyprogesterone (17OHP; IBL, Hamburg, Germany; detection limit $0.3 \mathrm{nmol} / \mathrm{l}$ ), and DHEA (Diagnostic Systems Laboratory, Webster, Texas; detection limit $0.13 \mathrm{nmol} / \mathrm{l}$ ) were measured by immunometric enzyme immunoassays. Serum leptin was measured by an enzyme linked immunosorbent assay (ELISA) with a detection limit of $7.8 \mathrm{pg} / \mathrm{ml}$ (R\&D Systems, Wiesbaden, Germany). As indicated by the suppliers, intra-assay and interassay coefficients of variation for all assays were below $10 \%$.

To demonstrate a preponderance of one serum hormone over another, the molar ratio of these hormones was calculated (given without unit). This procedure detects a hormonal shift through one to more adrenal enzyme steps which can demonstrate a preponderance of an adrenal pathway (fig 1): ASD/cortisol for P450c21, P450c11, and 17/ 20-lyase (2nd reaction of the P450cl7) into the direction of ASD, ASD/17OHP for the 17/20-lyase (2nd reaction of the P450c17) into the direction of ASD, and DHEA/ASD for the $3 \beta$-hydroxysteroid dehydrogenase into the direction of DHEA (fig 1).

\section{Statistical analysis}

Investigation of an interrelation between two variables was done using Spearman rank correlation analysis (SPSS/PC for Windows, versionl0.0.5, SPSS, Inc, Chicago). Medians within groups were compared by Mann-Whitney signed rank test (SPSS). To control an interrelation between two variables for a third control parameter partial correlation analysis was used (SPSS). Values of $\mathrm{p}<0.05$ were considered to be significant and results are given as mean (SEM).

\section{RESULTS}

In patients with SLE and RA, serum levels of ASD correlated negatively with serum leptin concentrations (fig 2) which was similar in the subgroups with and without prior prednisolone treatment (fig 2). In all patients with SLE and RA including those with prior prednisolone treatment, a highly significant interrelation existed (SLE: $R_{\text {Rank }}=-0.618$, $\mathrm{p}<0.0001$, and RA: $R_{\text {Rank }}=-0.601, \mathrm{p}<0.0001$, respectively). After controlling this interrelation for daily prednisolone dose this particular negative correlation remained significant (SLE: $R_{\text {partial }}=-0.483, \mathrm{p}=0.006$, and RA: $R_{\text {partial }}=-0.439$, $\mathrm{p}=0.028$, respectively). No such correlations were seen in HS (fig 2, lower panel).

To estimate the hormonal preponderance of ASD versus cortisol, the molar ratio of these two hormones was calculated. This ratio correlated negatively with serum leptin levels in all patients, including those with prior prednisolone treatment (fig 3). In patients with SLE, this interrelation remained significant after controlling for daily prednisolone dose $\left(R_{\text {partial }}=-0.556, \mathrm{p}=0.001\right)$. In contrast, in patients with RA controlling for prednisolone intake abolished the negative correlation between serum leptin and this particular ratio $\left(R_{\text {partial }}=-0.313, \mathrm{p}=0.210\right)$. In HS, no such negative correlation was seen (fig 3, lower panel).

To directly investigate the shift from 17-OHP to ASD, the molar ratio of these hormones was calculated (fig 1). In support of above mentioned results, this ratio also correlated negatively with serum leptin levels (fig 4). In addition, both in patients with SLE and RA this negative correlation remained significant after controlling for daily prednisolone dose (SLE: $R_{\text {partial }}=-0.400, \mathrm{p}=0.026$; $\mathrm{RA}: R_{\text {partial }}=-0.448$, $\mathrm{p}=0.022)$. These correlations were not significantly negative in HS (fig 4, lower panel).

These data clearly indicate a reduction of the adrenal androgen ASD in relation to upstream steroid hormones. To estimate the role of the $3 \beta$-hydroxysteroid dehydrogenase (fig 1), the molar ratio of DHEA/ASD was calculated (fig 1). Interestingly, this ratio correlated positively with serum leptin levels in all patients with SLE and RA (fig 5). This positive interrelation remained significant in those patients with SLE and RA without prior prednisolone treatment (SLE: 

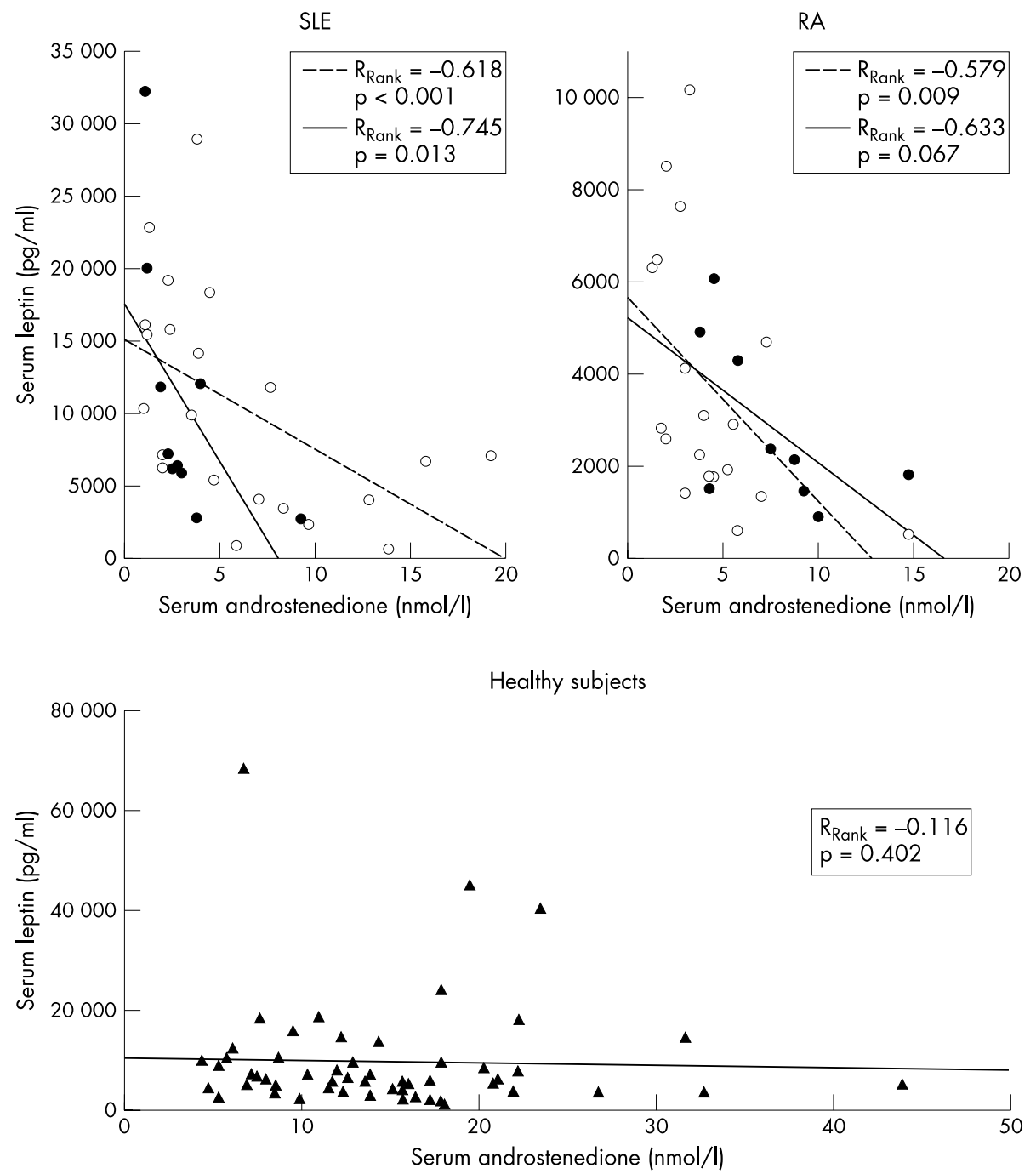

Figure 2 Interrelation between serum levels of ASD and leptin in patients with SLE, RA, and HS. Open symbols (broken line) stand for patients with prior prednisolone treatment whereas black symbols (solid line) represent patients without prior prednisolone treatment. The linear regression lines, the Spearman rank correlation coefficients $\left(R_{\text {Rank }}\right)$ and the $p$ values are given in the panels. Direct comparison of patients with SLE, RA, and HS is not meaningful because of the unknown body mass index (take notice of the different scales).

$\left.R_{\text {Rank }}=0.648, \mathrm{p}=0.043 ; \mathrm{RA}: R_{\text {Rank }}=0.833, \mathrm{p}=0.005\right)$. There was no such correlation in HS (fig 5, lower panel).

Because leptin serum levels were described as higher in women than in men, we compared our readout parameters between women and men within the respective disease groups. Serum leptin levels were higher in women than in men, and this difference was significant in HS and patients with RA (table 2). No differences were found for serum levels of ASD (table 2) and all calculated molar ratios (not shown).

\section{DISCUSSION}

This study demonstrates an inverse interrelation between serum levels of leptin and ASD or molar ratios of serum levels of ASD/cortisol or ASD/17OHP. This was accompanied by a positive correlation between serum leptin and the molar ratio of serum DHEA/serum ASD (fig 1). All these correlations were particularly stable in patients with SLE irrespective of prior prednisolone treatment.

Several recent studies demonstrated the inhibitory influence of leptin on gonadal and adrenocortical ASD production, ${ }^{29-31}$ which is achieved by direct inhibition of the respective $\mathrm{P} 450$ enzyme mRNA expression in steroid hormone producing cells. ${ }^{32}$ Our studies in chronic inflammatory diseases corroborate the possibility that leptin may have an inhibitory influence on ASD secretion which was not seen in our HS. In view of the known in vitro data of leptin induced inhibition of ASD (reviewed by Glasow and Bornstein ${ }^{33}$ ), our study supports the concept that the important enzyme step of the 17/20-lyase (2nd reaction of the P450cl7) is particularly altered in these patients (fig 1). Moreover, owing to the positive correlation between serum leptin and the molar ratio serum DHEA/serum ASD, 3 $\beta$-hydroxysteroid dehydrogenase may also be altered by leptin (not in HS). However, this latter fact has not been investigated in vitro in adrenocortical cells and, thus, remains to be elucidated. Because we and others believe that androgens are anti-inflammatory in chronic inflammatory diseases, their continuous reduction is unfavourable for the disease outcome. Loss of ASD would lead to a loss of testosterone and dihydrotestosterone (fig l). The question arises as to the more general role of leptin during an inflammatory episode and why leptin should have a proinflammatory role.

Leptin from adipose tissue is stimulated by proinflammatory cytokines such as TNF and interleukin $1 \beta$ which has been demonstrated several times. ${ }^{37-41}$ These cytokines seem to stimulate short term release of stored leptin, although its 

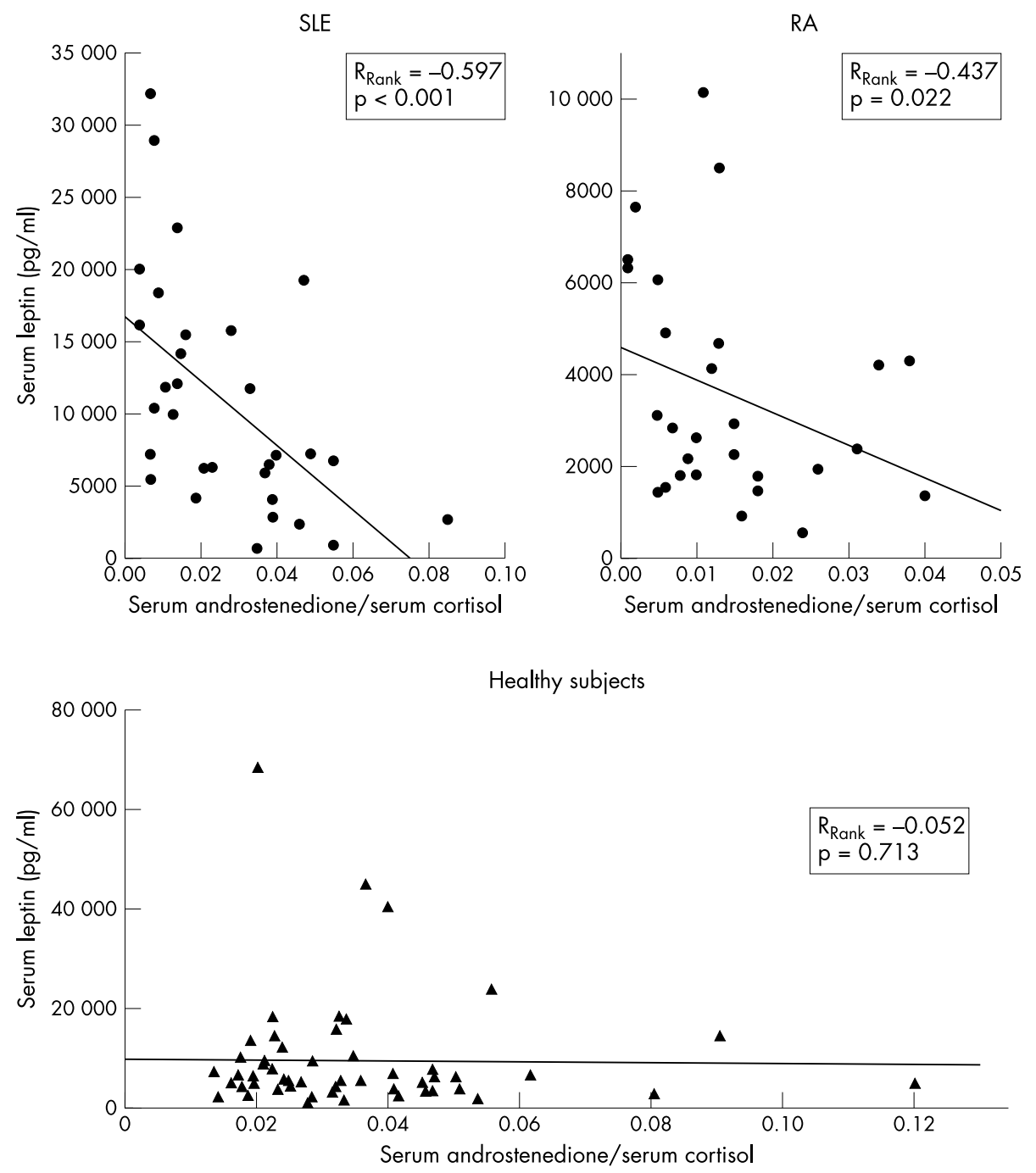

Figure 3 Interrelation between the molar ratio of serum ASD/serum cortisol and leptin in all patients with SLE, RA, and HS. In both disease groups, patients with and without prior prednisolone treatment were included. The linear regression line, the Spearman rank correlation coefficient $\left(R_{R a n k}\right)$ and the $p$ value are given in the panels. Direct comparison of patients with SLE, RA, and HS is not meaningful because of the unknown body mass index (take notice of different scales).

production may even be inhibited during long term in vitro stimulation with TNF. ${ }^{42}$ Thus, the acute cytokine driven rise in leptin may support the initial proinflammatory response. Indeed, human leptin stimulates proliferation and activation of human circulating monocytes through the leptin receptor, which is a member of the interleukin 6 receptor related cytokine receptors. ${ }^{43}$ Leptin is a fundamental factor for human $\mathrm{T}$ cell proliferation and it induces $\mathrm{T}$ helper type $\mathrm{l}$ immune reactions.$^{44}$ Moreover, fat mass in humans is directly related to white blood count, which is closely related to leptin serum levels, ${ }^{45}$ and leptin stimulates oxidative species production by stimulated polymorphonuclear neutrophils. ${ }^{46}$ Thus, leptin may be an "acute phase protein of fat tissue" which supports the immune system during a short term infectious disease. Indeed, leptin deficient mice exhibit impaired host defence in Gram negative pneumonia, ${ }^{47}$ and starvation with low serum leptin levels leads to immunosuppression. ${ }^{48}$ Interestingly, serum leptin levels are increased in survivors of sepsis as compared with non-survivors. ${ }^{49}$ All these factors indicate that leptin has been evolutionarily conserved for an acute inflammatory response. During some chronic inflammatory disease, serum levels of leptin are also increased..$^{50-52}$ In our study we could not confirm this fact because we did not match for body mass index and age (thus, comparison of the groups is not allowed). As in the acute infectious condition, most probably the proinflammatory load increases serum leptin which depends on fat mass. One may speculate that leptin is a systemic indicator of the available energy resources: it may be necessary for the fine tuning of the vastly energy consuming immune response. In this respect, it supports the proinflammatory pathways of the immune system.

In view of these general immune supportive aspects of leptin, leptin is probably a proinflammatory mediator which was evolutionarily saved for the acute inflammatory episode. In this respect, inhibition of leptin induced androgens is an indication of its proinflammatory role. TNF, like leptin, directly inhibits adrenal steroidogenesis by modulating P450c17 and others. ${ }^{53}$ In a recent long term study in patients with RA, anti-TNF treatment obviously favoured androgen secretion, which demonstrates the detrimental influence of this cytokine on androgens. ${ }^{54}$ Because both TNF and leptin can inhibit androgen secretion in parallel, one may speculate that the negative correlations between serum leptin and ASD (and ratios) are only to be found in patients with a high proinflammatory load and, thus, did not occur in our HS. 
SIE

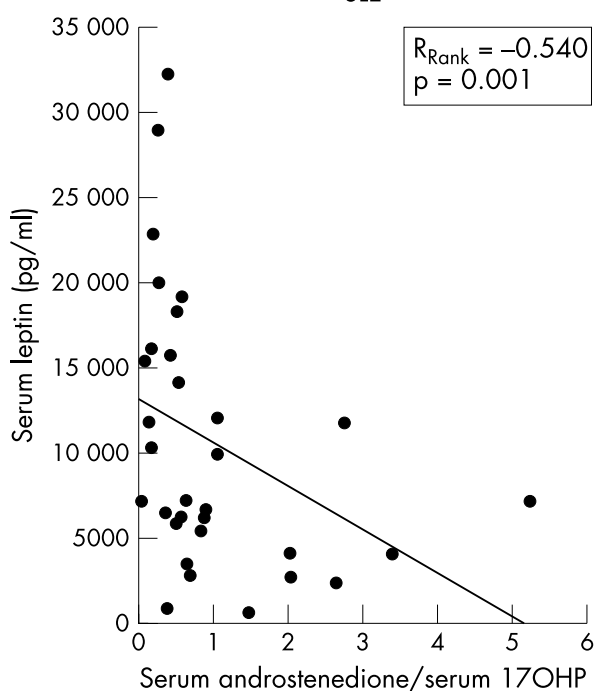

RA

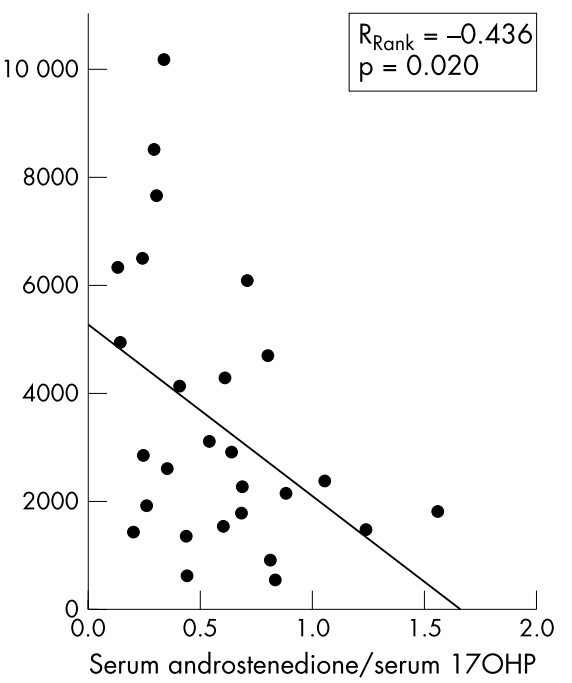

Healthy subjects

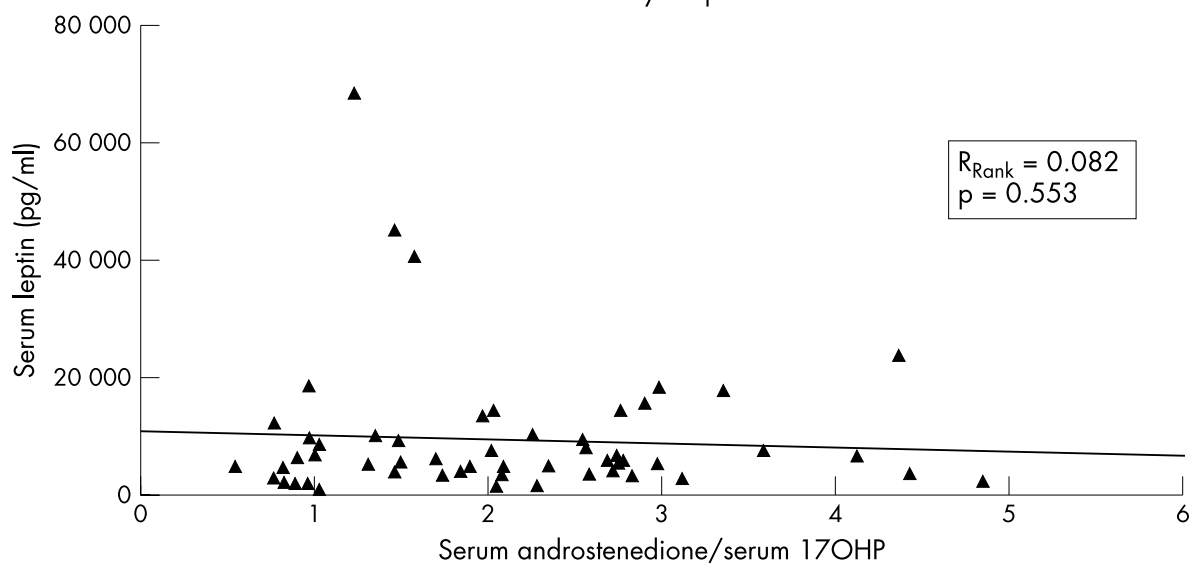

Figure 4 Interrelation between the molar ratio of serum ASD/serum 17OHP and leptin in all patients with SLE, RA, and HS. In both disease groups, patients with and without prior prednisolone treatment were included. The linear regression line, the Spearman rank correlation coefficient $\left(R_{R a n k}\right)$ and the $p$ value are given in the panels. Direct comparison of patients with SLE, RA, and HS is not meaningful because of the unknown body mass index (take notice of the different scales).

In conclusion, in patients with SLE and RA our study supports the known concept that leptin inhibits androstenedione secretion. In chronic inflammatory diseases, this phenomenon may add to the well known hypoandrogenicity.
Because leptin is a proinflammatory mediator and androgens are anti-inflammatory, preponderance of leptin and hypoandrogenicity may help to perpetuate chronic inflammatory diseases.

Table 2 Basic characteristics of healthy subjects and patients with systemic lupus erythematosus (SLE) and rheumatoid arthritis (RA)

\begin{tabular}{|c|c|c|c|}
\hline & Women & Men & p Value \\
\hline \multicolumn{4}{|l|}{ Healthy subjects } \\
\hline Serum leptin (pg/ml) & $14490(2946)$ & $4715(610)$ & $<0.001$ \\
\hline Serum ASD (nmol/l) & $13.5(1.3)$ & $15.6(1.6)$ & NS \\
\hline \multicolumn{4}{|c|}{ Systemic lupus erythematosus } \\
\hline Serum leptin (pg/ml) & 11999 (1643) & 6319 (2167) & 0.064 \\
\hline Serum ASD (nmol/l) & $4.6(0.9)$ & $6.7(2.0)$ & NS \\
\hline \multicolumn{4}{|l|}{ Rheumatoid arthritis } \\
\hline Serum leptin (pg/ml) & $3973(572)$ & $2186(554)$ & 0.047 \\
\hline Serum ASD (nmol/l) & $1.9(0.3)$ & $3.0(0.6)$ & NS \\
\hline \multicolumn{4}{|c|}{$\begin{array}{l}\text { Data are given as means (SEM). } \\
\text { ASD, androstenedione. } \\
\text { The values are not given for comparison of subgroups because body mass index was not available. For this } \\
\text { particular leptin assay, the supplier provided mean values for women and men of } 20676 \mathrm{pg} / \mathrm{ml} \text { (range } 3877- \\
77273 \text { ) and } 4760 \mathrm{pg} / \mathrm{ml} \text { (2205-11 149), respectively (R\&D Systems, Wiesbaden, Germany). }\end{array}$} \\
\hline
\end{tabular}


SLE

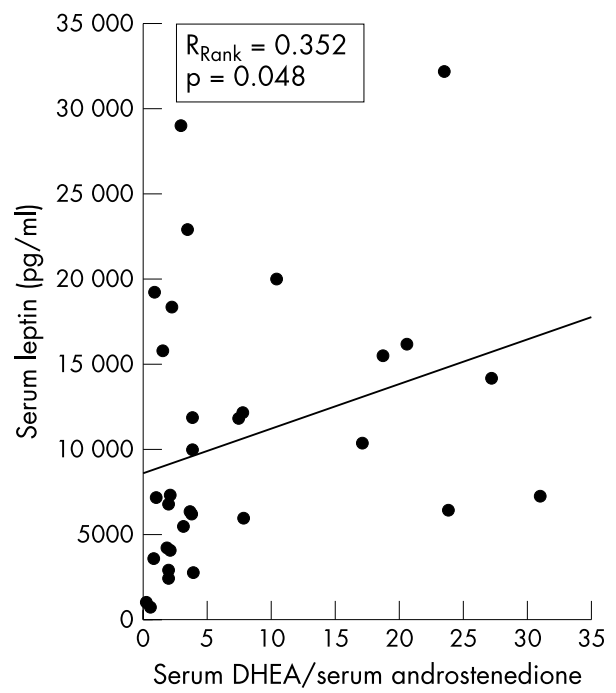

RA

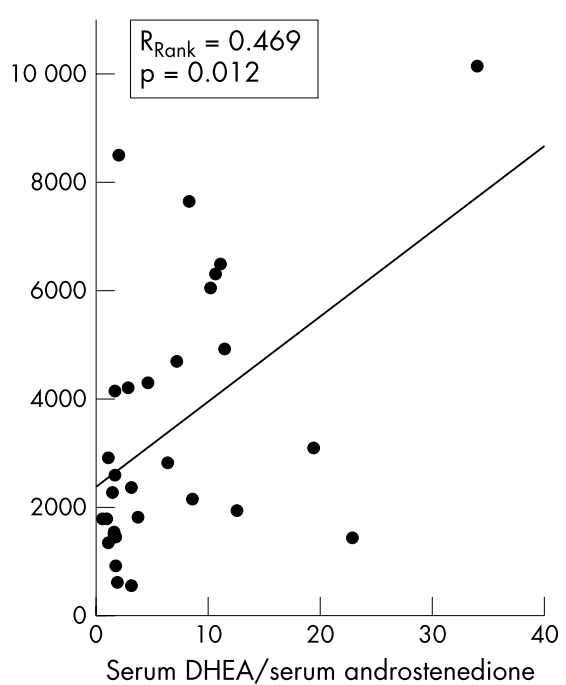

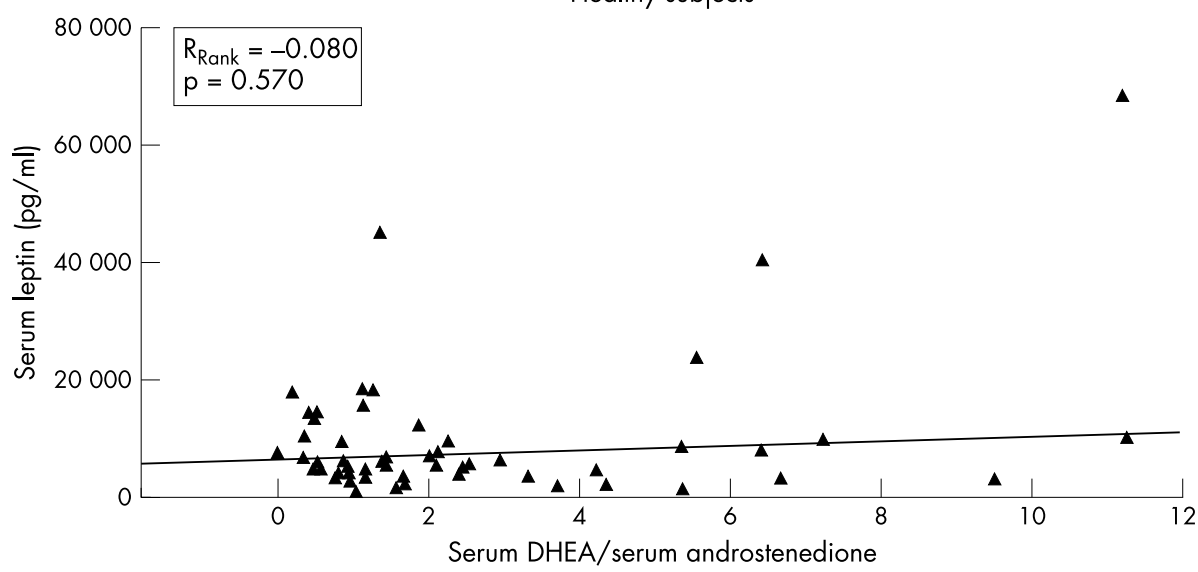

Figure 5 Interrelation between the molar ratio of serum (DHEA)/serum ASD and serum leptin in all patients with SLE, RA, and HS. In both disease groups, patients with and without prior prednisolone treatment were included. The linear regression line, the Spearman rank correlation coefficient $\left(R_{\text {Rank }}\right)$, and the $p$ value are given in the panels. Direct comparison of patients with SLE, RA, and HS is not meaningful because of the unknown body mass index (take notice of different scales).

\section{ACKNOWLEDGEMENTS}

Part of this study was funded by the Deutsche Forschungsgemeinschaft (Str $511 / 10-1)$ and by the institution.

\section{Authors' affiliations}

P Härle, G Pongratz, C Weidler, R Büttner, J Schölmerich, R H Straub, Laboratory of Neuro/endocrino/immunology, Division of Rheumatology, Department of Internal Medicine I, University Hospital Regensburg, D-93042 Regensburg, Germany

\section{REFERENCES}

1 Feher GK, Feher T, Zahumenszky Z. Study on the inactivation mechanism of androgens in rheumatoid arthritis: excretory rate of free and conjugated 17ketosteroids. Endokrinologie 1979;73:167-72.

2 Masi AT, Josipovic DB, Jefferson WE. Low adrenal androgenic-anabolic steroids in women with rheumatoid arthritis (RA): gas-liquid chromatographic studies of RA patients and matched normal control women indicating decreased 11-deoxy-17-ketosteroid excretion. Semin Arthritis Rheum 1984; 14:1-23.

3 Cutolo M, Balleari E, Giusti M, Monachesi M, Accardo S. Sex hormone status of male patients with rheumatoid arthritis: evidence of low serum concentrations of testosterone at baseline and after human chorionic gonadotropin stimulation. Arthritis Rheum 1988;31:1314-17.

4 Sambrook PN, Eisman JA, Champion GD, Pocock NA. Sex hormone status and osteoporosis in postmenopausal women with rheumatoid arthritis. Arthritis Rheum 1988;31:973-8.
5 Deighton CM, Watson MJ, Walker DJ. Sex hormones in postmenopausal HLA-identical rheumatoid arthritis discordant sibling pairs. J Rheumatol 1992;19:1663-7.

6 Hedman M, Nilsson E, de la Torre B. Low blood and synovial fluid levels of sulpho-conjugated steroids in rheumatoid arthritis. Clin Exp Rheumatol 1992;10:25-30.

7 Valentino R, Savastano S, Tommaselli AP, Riccio A, Mariniello P, Pronesti G, et al. Hormonal pattern in women affected by rheumatoid arthritis. J Endocrinol Invest 1993;16:619-24

8 Mateo L, Nolla JM, Bonnin MR, Navarro MA, Roig-Escofet D. Sex hormone status and bone mineral density in men with rheumatoid arthritis. J Rheumatol 1995;22:1455-60.

9 Mirone L, Altomonte L, D'Agostino P, Zoli A, Barini A, Magaro M. A study of serum androgen and cortisol levels in female patients with rheumatoid arthritis. Correlation with disease activity. Clin Rheumatol 1996;15:15-19.

10 Nilsson E, de la Torre B, Hedman M, Goobar J, Thorner A. Blood dehydroepiandrosterone sulphate (DHEAS) levels in polymyalgia rheumatica/ giant cell arteritis and primary fibromyalgia. Clin Exp Rheumatol 1994; 12:415-17.

11 Reincke M, Heppner C, Petzke F, Allolio B, Arlt W, Mbulamberi D, et al. Impairment of adrenocortical function associated with increased plasma tumor necrosis factor-alpha and interleukin-6 concentrations in African trypanosomiasis. Neuroimmunomodulation 1994;1:14-22.

12 Reincke $M$, Lehmann R, Karl M, Winkelmann W, Allolio B. Veränderungen der Nebenierenfunktion bei Schwerstkranken. In: Allolio B, Benker G, Schulte HM, eds. Nebeniere und Stress. Stuttgart: Schattauer Verlag, 1995:189-99.

13 de la Torre B, Fransson J, Scheynius A. Blood dehydroepiandrosterone sulphate (DHEAS) levels in pemphigoid/pemphigus and psoriasis. Clin Exp Rheumatol 1995; 13:345-8. 
14 Straub RH, Zeuner M, Lock G, Schölmerich J, Lang B. High prolactin and low dehydroepiandrosterone sulphate serum levels in patients with severe systemic sclerosis. BrJ Rheumatol 1997;36:426-32.

15 Tabata N, Tagami H, Terui T. Dehydroepiandrosterone may be one of the regulators of cytokine production in atopic dermatitis. Arch Dermatol Res 1997;289:410-14.

16 Straub RH, Vogl D, Gross V, Lang B, Schölmerich J, Andus T. Association of humoral markers of inflammation and dehydroepiandrosterone sulfate or cortisol serum levels in patients with chronic inflammatory bowel disease. Am J Gastroenterol 1998;93:2197-202.

17 Kumpfel T, Then BF, Friess E, Uhr M, Yassouridis A, Trenkwalder C, et al Dehydroepiandrosterone response to the adrenocorticotropin test and the combined dexamethasone and corticotropin-releasing hormone test in patients with multiple sclerosis. Neuroendocrinology 1999:70:431-8.

18 Straub RH, Cutolo M. Involvement of the hypothalamic-pituitary-adrenal/ gonadal axis and the peripheral nervous system in rheumatoid arthritis: viewpoint based on a systemic pathogenetic role. Arthritis Rheum 2001;44:493-507.

19 Cutolo M, Wilder R. Different roles for androgens and estrogens in the susceptibility to autoimmune rheumatic diseases. Rheum Dis Clin North Am 2000;26:825-39.

20 van Vollenhoven RF, Engleman EG, McGuire JL. Dehydroepiandrosterone in systemic lupus erythematosus. Results of a double-blind, placebo-controlled, randomized clinical trial. Arthritis Rheum 1995;38:1826-31.

21 Chang DM, Lan JL, Lin HY, Luo SF. Dehydroepiandrosterone treatment of women with mild-to-moderate systemic lupus erythematosus: a multicenter randomized, double-blind, placebo-controlled trial. Arthritis Rheum 2002;46:2924-7.

22 Petri MA, Lahita RG, van Vollenhoven RF, Merrill JT, Schiff M, Ginzler EM, et al. Effects of prasterone on corticosteroid requirements of women with systemic lupus erythematosus: a double-blind, randomized, placebocontrolled trial. Arthritis Rheum 2002:46:1820-9.

23 Andus T, Klebl F, Rogler G, Bregenzer N, Schölmerich J, Straub RH. Patients with refractory Crohn's disease or ulcerative colitis respond to dehydroepiandrosterone: a pilot study. Aliment Pharmacol Ther 2003; 17:409-14.

24 Zumoff B, Strain GW, Miller LK, Rosner W, Senie R, Seres DS, et al. Plasma free and non-sex-hormone-binding-globulin-bound testosterone are decreased in obese men in proportion to their degree of obesity. J Clin Endocrinol Metab 1990;71:929-31

25 Armellini F, Zamboni M, Castelli S, Robbi R, Mino A, Todesco T, et al. Interrelationships between intraabdominal fat and total serum testosterone levels in obese women. Metabolism 1994;43:390-5.

26 Zhang Y, Proenca R, Maffei M, Barone M, Leopold L, Friedman JM. Positional cloning of the mouse obese gene and its human homologue. Nature 1994:372:425-32.

27 Fantuzzi G, Faggioni R. Leptin in the regulation of immunity, inflammation, and hematopoiesis. J Leukoc Biol 2000;68:437-46.

28 Gambineri A, Pasquali R. Testosterone therapy in men: clinical and pharmacological perspectives. J Endocrinol Invest 2000;23:196-214

29 Spicer LJ, Francisco CC. Adipose obese gene product, leptin, inhibits bovine ovarian thecal cell steroidogenesis. Biol Reprod 1998;58:207-12.

30 Agarwal SK, Vogel K, Weitsman SR, Magoffin DA. Leptin antagonizes the insulin-like growth factor-I augmentation of steroidogenesis in granulosa and theca cells of the human ovary. J Clin Endocrinol Metab 1999;84:1072-6.

31 Spicer U, Chamberlain CS, Francisco CC. Ovarian action of leptin: effects on insulin-like growth factor-I-stimulated function of granulosa and thecal cells. Endocrine 2000; 12:53-9.

32 Kruse M, Bornstein SR, Uhlmann K, Paeth G, Scherbaum WA. Leptin down regulates the steroid producing system in the adrenal. Endocr Res 1998;24:587-90.

33 Glasow A, Bornstein SR. Leptin and the adrenal gland. Eur J Clin Invest 2000;30(suppl 3):39-45

34 Arnett FC, Edworthy SM, Bloch DA, McShane DJ, Fries JF, Cooper NS, et al. The American Rheumatism Association 1987 revised criteria for the classification of rheumatoid arthritis. Arthritis Rheum 1988;31:315-24.
35 Tan EM, Cohen AS, Fries JF, Masi AT, McShane DJ, Rothfield NF, et al. The 1982 revised criteria for the classification of systemic lupus erythematosus. Arthritis Rheum 1982;25:1271-7.

36 Straub RH, Konecna L, Hrach S, Rothe G, Kreutz M, Schölmerich J, et al. Serum dehydroepiandrosterone (DHEA) and DHEA sulfate are negatively correlated with serum interleukin-6 (IL-6), and DHEA inhibits IL-6 secretion from mononuclear cells in man in vitro: possible link between endocrinosenescence and immunosenescence. J Clin Endocrinol Metab 1998;83:2012-17.

37 Kirchgessner TG, Uysal KT, Wiesbrock SM, Marino MW, Hotamisligil GS. Tumor necrosis factor-alpha contributes to obesity-related hyperleptinemia by regulating leptin release from adipocytes. J Clin Invest 1997:100:2777-82

38 Zumbach MS, Boehme MW, Wahl P, Stremmel W, Ziegler R, Nawroth PP. Tumor necrosis factor increases serum leptin levels in humans. J Clin Endocrinol Metab 1997;82:4080-2.

39 Faggioni R, Fantuzzi G, Fuller J, Dinarello CA, Feingold KR, Grunfeld C. IL-1 beta mediates leptin induction during inflammation. Am J Physiol 1998;274:R204-8.

40 Finck BN, Kelley KW, Dantzer R, Johnson RW. In vivo and in vitro evidence for the involvement of tumor necrosis factor-alpha in the induction of leptin by lipopolysaccharide. Endocrinology 1998;139:2278-83.

41 Finck BN, Johnson RW. Tumor necrosis factor (TNF)-alpha induces leptin production through the p55 TNF receptor. Am J Physiol Regul Integr Comp Physiol 2000;278:R537-43.

42 Zhang HH, Kumar S, Barnett AH, Eggo MC. Tumour necrosis factor-alpha exerts dual effects on human adipose leptin synthesis and release. Mol Cell Endocrinol 2000;159:79-88.

43 Santos-Alvarez J, Goberna R, Sanchez-Margalet V. Human leptin stimulates proliferation and activation of human circulating monocytes. Cell Immunol 1999;194:6-11.

44 Lord GM, Matarese G, Howard JK, Baker RJ, Bloom SR, Lechler RI. Leptin modulates the T-cell immune response and reverses starvation-induced immunosuppression. Nature 1998;394:897-901.

45 Wilson CA, Bekele G, Nicolson M, Ravussin E, Pratley RE. Relationship of the white blood cell count to body fat: role of leptin. Br J Haematol 1997:99:447-51

46 Caldefie-Chezet F, Poulin A, Tridon A, Sion B, Vasson MP. Leptin: a potential regulator of polymorphonuclear neutrophil bactericidal action? J Leukoc Biol 2001;69:414-18

47 Mancuso P, Gottschalk A, Phare SM, Peters-Golden M, Lukacs NW Huffnagle GB. Leptin-deficient mice exhibit impaired host defense in Gramnegative pneumonia. J Immunol 2002;168:4018-24.

48 Faggioni R, Feingold KR, Grunfeld $C$. Leptin regulation of the immune response and the immunodeficiency of malnutrition. FASEB $J$ $2001 ; 15: 2565-71$

49 Bornstein SR, Licinio J, Tauchnitz R, Engelmann L, Negrao AB, Gold P, et al. Plasma leptin levels are increased in survivors of acute sepsis: associated loss of diurnal rhythm, in cortisol and leptin secretion. J Clin Endocrinol Metab 1998;83:280-3.

50 Anders HJ, Rihl M, Heufelder A, Loch O, Schattenkirchner M. Leptin serum levels are not correlated with disease activity in patients with rheumatoid arthritis. Metabolism 1999:48:745-8.

51 Garcia-Gonzalez A, Gonzalez-Lopez L, Valera-Gonzalez IC, CardonaMunoz EG, Salazar-Paramo M, Gonzalez-Ortiz M, et al. Serum leptin levels in women with systemic lupus erythematosus. Rheumatol Int 2002;22:138-41.

52 Kimata H. Elevated serum leptin in AEDS. Allergy 2002;57:179.

53 Jäättelä M, Ilvesmaki V, Voutilainen R, Stenman UH, Saksela E. Tumor necrosis factor as a potent inhibitor of adrenocorticotropin-induced cortisol production and steroidogenic P450 enzyme gene expression in cultured human fetal adrenal cells. Endocrinology 1991;128:623-9.

54 Straub RH, Pongratz G, Schölmerich J, Kees F, Schaible TF, Antoni C, et al. Long-term anti-TNF antibody therapy in rheumatoid arthritis patients sensitizes the pituitary gland and favors adrenal androgen secretion. Arthritis Rheum 2003:48:1504-12. 